DOI: 10.20472/IAC.2018.042.034

\title{
TAKASHI NAKAMURA
}

tokyo city university, Japan

\section{MAINTENANCE OF THE RAILWAY USER $\square$ UNDER $\square$ THE AGING SOCIETY IN TOKYO METROPOLITAN SUBURBAN AREA}

\begin{abstract}
:
Japan has been facing problems related to decline of population and aging. Also Tokyo metropolitan area is estimated depopulation and hard aging. Additionally a new urban planning that targets the reduction of automobile dependence and the use of public transit is required for realization of sustainable city. Tokyo metropolitan area is originally excellent in railway usage on commuting transit. Under this situation it is important that railway passengers preserve. I study the influence of land use patterns, aging and traffic means to railway station around above 580 railway stations on railway passengers from the viewpoint of sustainable rail transit service, especially viewpoint of TOD (Transit Oriented Development) using multiple regression analysis. In this study I set railway station influence area $800 \mathrm{~m}$ in land use analysis and $500 \mathrm{~m}$ in population aging analysis. I use railway passenger's data from 1999 to 2015. In this study land use classification is farmland, forest, low-rise housing, crowd low-rise housing, middle and high-rise housing, commercial and business use, park and green land, manufacturing, public institution and development land. Traffic means to railway station in this study analysis are bicycle, bus, motor bicycle and working. As a result, it's found that aging around railway station affect decrease railway passengers and mixed land use around railway stations has a constant effect on the increase and retention of the number of railway passengers. On the other hand, traffic means to railway station is not related to maintenance of the railway user. In addition aging around railway station is related to land use. Namely, in high component of low-rise housing areas hard aging is advancing. I will introduce success example of railway passengers' maintenance. It is important to perform mixed land use around railway station, urban redevelopment around railway station at high component of low-rise housing area, especially, unplanned sprawl area.
\end{abstract}

\section{Keywords:}

TOD; land use pattern; passengers of railway station; mixed land use; population aging. traffic means to railway station, multiple regression analysis

JEL Classification: R58, R14, L92 